\title{
Pneumologia
}

\section{Hypersensitivity pneumonitis - acceptance of the diagnosis}

\author{
Patricia Hogea ${ }^{1}$, Emanuela Tudorache ${ }^{1,2, *}$, Zsolt Vastag ${ }^{3}$, Andrada Gârjoabă $^{3}$, Cristian Oancea ${ }^{1,2}$
}

${ }^{1}$ Department of Respiratory Medicine I, "Dr. Victor Babeș" Clinical Hospital of Infectious Diseases and Pneumology, Timișoara, Romania

${ }^{2}$ Department XIII - Respiratory Medicine, "Dr. Victor Babeș” University of Medicine and Pharmacy, Timișoara, Romania

${ }^{3}$ Department of Respiratory Medicine II, "Dr. Victor Babeș” Clinical Hospital of Infectious Diseases and Pneumology, Timișoara, Romania

Abstract

English:

Hypersensitivity pneumonia (HP) is an inflammatory lung syndrome due to repetitive exposure to small organic particles. The etiological agents of the disease are diverse and can be represented by fungi, bacteria, small molecule chemical compounds, as well as proteins from animals or insects. We present the case of a 25-year-old male, who was admitted to our Pulmonology Clinic for the following symptoms: morning cough with mucosal sputum for about 2 years, moderate exertional dyspnea (mMRC 3) started for 2 months, weight loss of about $6 \mathrm{~kg}$ in the past 5 months and fatigue. Clinical examination revealed bilateral midbasal crackling rales. Chest high-resolution computed tomography (HRCT) (multiple micronodular opacities, diffuse contoured, bilaterally disseminated), lung function tests (restrictive ventilatory dysfunction with decreased carbon monoxide diffusing capacity), bronchoalveolar lavage (BAL) (lymphocyte alveolitis) and serological tests (positive antibodies for pigeon heathers and dejections) pointed to the diagnosis of hypersensitivity pneumonitis. It was recommended to avoid exposure to pigeons, as the patient was a pigeon breeder. Prednisone treatment was initiated. The general condition of the patient 1 month after diagnosis had improved, the evolution being good under treatment.

Keywords

\section{Pneumonita de hipersensibilitate - acceptarea diagnosticului}

Rezumat

\section{Romanian:}

Pneumonita de hipersensibilitate reprezintă un sindrom inflamator pulmonar determinat de expunerea repetitivă la particule organice mici. Agenții etiologici ai bolii sunt diverși, putând fi reprezentați de fungi, bacterii, compuși chimici cu moleculă mică, precum și proteine provenite de la animale sau de la insecte. Prezentăm cazul unui pacient de sex masculin în varstă de 25 ani, care s-a internat în Clinica de Pneumologie pentru următoarele acuze: tuse matinală cu expectorație mucoasă de aproximativ doi ani, dispnee la efort moderat (mMRC 3) debutată de două luni, scădere în greutate aproximativ 6 kg în ultimele cinci luni și fatigabilitate. La examenul clinic se decelează raluri crepitante medio-bazal bilateral. În urma efectuării computer tomografiei de înaltă rezoluție de torace (multiple opacităti micronodulare, difuz conturate, diseminate bilateral), a testelor funcționale respiratorii (disfuncție ventilatorie restrictivă, cu difuziunea alveolocapilară scăzută), a lavajului bronho-alveolar (alveolită limfocitară) si a testelor serologice (anticorpi pozitivi pentru pene si dejectii de porumbel) se stabileste diagnosticul de pneumonită de hipersensibilitate. S-a recomandat evitarea expunerii la porumbei, pacientul fiind crescător de porumbei. A fost inițiat tratamentul cu prednison. Starea generală a pacientului la o lună de la diagnostic s-a îmbunătățit, evoluția fiind favorabilă sub tratament.

Cuvinte-cheie

pneumonită de hipersensibilitate • expunere profesională • lavaj bronho-alveolar

*Corresponding author: Emanuela Tudorache

E-mail: tudorache_emanuela@yahoo.com 


\section{Introduction}

Hypersensitivity pneumonia (HP) or extrinsic allergic alveolitis is an inflammatory and/or fibrotic pulmonary disease due to repetitive exposure to small organic particles. The inflammatory process involves the small airways and the interstitium. The disease occurs in susceptible people and can affect both adults and children $(1,2)$. Antigens involved in the development of HP have a diameter of $<5 \mu \mathrm{m}$, which allows inhalation into the tracheobronchial tree and their deposition at the alveolar level (3). More than 300 antigens capable of causing HP are described, and they can be classified into bacteria, fungi, animal proteins, plant proteins, low-molecular weight chemicals and metals. Exposure to these antigens usually occurs in certain occupations or hobbies, but can also occur in the home or immediate environment (4-6). The latest guide classifies this disease into fibrotic HP and nonfibrotic HP based on the presence or absence of radiological and/ or histopathological fibrosis. This new classification is considered more objective, reflects the severity of the disease at the time of diagnosis and can assess the clinical course and other outcomes (1).

\section{Case report}

We present the case of a 25-year-old male patient, with no known personal pathological history, who was admitted to the Pulmonology Clinic of Timișoara for morning cough with mucous sputum for about 2 years, dyspnea during moderate physical effort (mMRC 3 ) started 2 months ago, weight loss of $6 \mathrm{~kg}$ during the past 5 months and fatigue. The patient worked in construction and was a pigeon breeder. The respiratory examination revealed bilateral mid-basal crackles and oxygen saturation of $93 \%$ at rest.

Chest high-resolution computed tomography (HRCT) showed the presence of multiple diffusely contoured centrilobular micronodules, with ground-glass intensity, disseminated on both the lung fields (Figure 1).

Some images are artefacts due to the patient's nonobservance of respiratory times.

Spirometry showed moderate to severe restrictive ventilatory dysfunction ( $\mathrm{FEV}_{1} 2.58 \mathrm{~L} ; 59 \%$ of predicted). The carbon monoxide diffusing capacity (Dlco) was severely low (13.31 $\mathrm{mL} / \mathrm{min} / \mathrm{mmHg} ; 37.5 \%$ of predicted), associated with a slight-moderate decrease of the transfer constant $\left(\mathrm{K}_{\mathrm{CO}} 3.25 \mathrm{~mL} / \mathrm{min} / \mathrm{mmHg} / \mathrm{L} ; 64 \%\right.$ of predicted), the changes being suggestive of a restrictive syndrome of parenchymal nature.

The analysis of bronchoalveolar lavage $(B A L)$ fluid showed the presence of an increased total number of cells, macrophages with vacuolated cytoplasm and an increase in the number of lymphocytes (64.9\%), the appearance being suggestive of lymphocyte alveolitis (Figure 2).

Immunoglobulin $\mathrm{G}$ ( $\mathrm{lgG}$ ) of pigeon feathers and droppings were measured, the values being highly positive, which denoted the patient's sensitization to pigeons.

Following the clinical examination and the results obtained in the paraclinical tests, the diagnosis of nonfibrotic hypersensitivity pneumonitis was established. It was recommended to avoid contact with pigeons, and drug treatment with prednisone $40 \mathrm{mg} /$ day was initiated in the first month, $30 \mathrm{mg} /$ day in the second month, $20 \mathrm{mg} /$ day in the third month and $10 \mathrm{mg} /$ day in the fourth month. At the time of communication of the diagnosis, the patient hardly
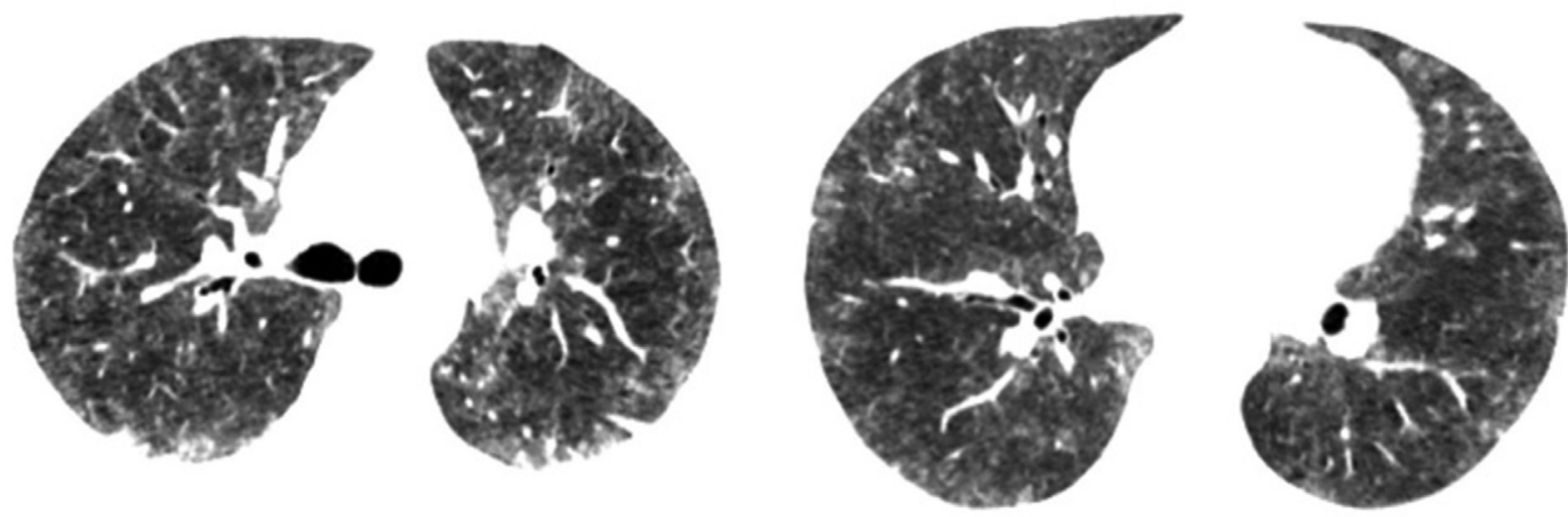

Figure 1. HRCT - multiple centrilobular micronodules diffuse contoured, with ground-glass intensity, disseminated on both lung fields. HRCT, high-resolution computed tomography. 

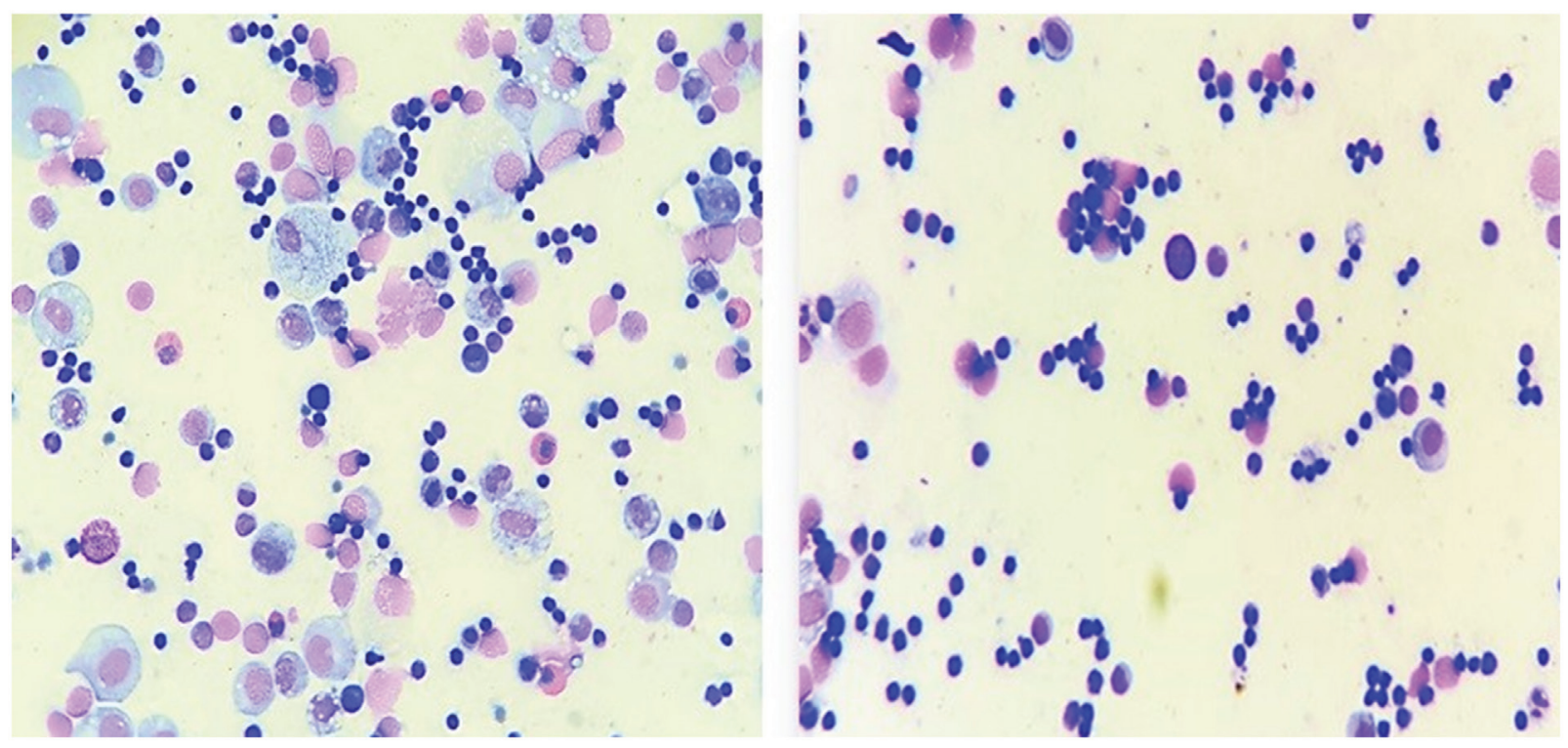

Figure 2. Lymphocyte alveolitis in BAL. BAL, bronchoalveolar lavage.

accepted it, denying that there could be such a lung disease. Raising pigeons was a hobby for him, and the decision to give them up was a difficult one. The patient is now in the second month of treatment, the evolution being good, with the remission of symptoms, normalization of oxygen saturation ( $\mathrm{SpO} 2=98 \%$ at rest) and increased tolerance to effort. During this period, the patient stated that he avoided contact with the pigeons most of the time or wore protective equipment.

\section{Discussion}

The prevalence of HP is difficult to evaluate and varies with the geographical climate, occupational and environmental exposures, and hostrisk factors. In the literature, the incidence of the disease is estimated between 0.3 and 0.9 per 100,000 individuals. In Europe, according to records of interstitial lung disease (ILD), HP accounts for $4-15 \%$ of all ILD cases $(1,4,5)$. Regardless of the type of HP, patients can experience signs and symptoms such as dyspnea, cough, chest tightness and mid-inspiratory squeaks. Less often they can have a fever, chills, weight loss, wheezing and cyanosis $(1,7)$. The diagnosis of $\mathrm{HP}$ is often difficult because there is no gold standard test. It is necessary to perform a detailed anamnesis regarding the exposure to various antigens, associated with imaging investigations, laboratory tests and pathological examination. Therefore, a multidisciplinary team, including a pulmonologist, radiologist, pathologist and occupational physician, is needed for accurate diagnosis $(1,4)$.

HRCT is the first imaging modality for the evaluation of patients with HP. The radiological pattern encountered in the nonfibrotic form of HP is represented by the presence of ground-glass opacity (GGO), mosaic attenuation, centrilobular nodules on inspiratory images and air trapping on expiratory images. In the fibrotic form of HP, the following radiological changes are described: lung fibrosis as irregular fine or coarse reticulation with architectural lung distortion and with septal thickening, traction bronchiectasis and honeycombing. The lesions are mainly localized at the level of the mid-and upper-lung zone, but also a diffuse pattern can be encountered with lower and peripheral lung distribution (1-3, 5).

Pulmonary function tests often show a restrictive ventilatory pattern with reduced $\mathrm{DL}_{\mathrm{co}}$. These tests define the severity of the disease, monitor the progression of the disease, and predict prognosis $(3,4)$. An increased level of serum precipitins (IgG antibodies) for the incriminated antigen may occur in HP but are not diagnostic. A positive IgG antibody only indicates patient exposure $(4,7)$.

$B A L$ is a useful method to detect lung inflammation in $\mathrm{HP}$. The cellular profile of BAL in HP is represented by an increase in the total cell count and an important elevation in the percentage of lymphocytes, which often exceeds $50 \%$. Alveolar macrophages may exhibit a foamy appearance in $\mathrm{HP}$, which indicates an intense process of phagocytosis. $B A L$ is not diagnostic of HP but supports the diagnosis $(6,8,9)$. 
If the diagnosis cannot be established by the methods described above, a lung biopsy will be considered. Nonfibrotic HP is characterized by non-necrotizing granulomatous interstitial bronchiolocentric pneumonitis, with inflammation characterized by lymphocytes. The fibrotic form is characterized by fibrotic changes with architectural distortion superimposed on the nonfibrotic findings $(1,6)$.

Early diagnosis associated with avoidance of the causative agent may slow the progression of lesions. The disease is usually reversible if the causative agent is avoided and fibrotic lesions are not formed. Complete avoidance of the incriminated antigen is often impossible, either because the causative agent cannot be identified, or its avoidance leads to major changes in the patient's lifestyle $(2,5)$. Corticosteroids are recommended for faster remission of the disease and in patients with severe symptoms. Their use does not affect the long-term outcome. It starts with prednisone in doses from $0.5 \mathrm{mg} / \mathrm{kg} /$ day to $1 \mathrm{mg} / \mathrm{kg} / \mathrm{day}$ (up to a maximum of $60 \mathrm{mg} /$ day). High doses are used for 2-4 weeks, depending on the severity, after which they are progressively reduced to the lowest therapeutic dose. In the absence of proper management, the disease progresses to pulmonary fibrosis, which most likely requires a lung transplant $(1,2,5)$.

\section{Conclusions}

Our patient developed HP secondary to his hobby of pigeon breeding. In the period after diagnosis, the patient tried to avoid exposure to pigeons, but not completely. Given that pigeons are kept in the same home, we believe that complete avoidance of antigens is not possible. The patient's evolution was good under prednisone treatment, but after the end of the treatment, recurrences can occur if the patient does not decide to give up this hobby. We also consider it very important for the patient to understand his disease and what causes it.

The use of respiratory protective equipment is not fully effective in preventing the fibrotic form of HP (10). Complete avoidance of the identified antigen is the most important measure to prevent disease progression and the development of pulmonary fibrosis.

\section{Ethical approval}

Informed consent was obtained from the patient before publishing the article.

\section{Conflict of interest}

The authors declare that they have no conflicts of interest.

\section{References}

1. Raghu G, Wilson KC, Bargagli E, Bendstrup E, Chami HA, Chua AT, et al. Diagnosis of hypersensitivity pneumonitis in adults: An official ATS/JRS/ALAT clinical practice guideline. American Journal of Respiratory and Critical Care Medicine. 2020;202(3): e36-e69.

2. Miller R, Allen TC, Barrios RJ, Beasley MB, Burke L, Cagle PT, et al. Hypersensitivity pneumonitis: A perspective from members of the pulmonary pathology society. Archives of Pathology \& Laboratory Medicine. 2018;142(1): 120-126.

3. Magee AL, Montner SM, Husain A, Adegunsoye A, Vij R, Chung $\mathrm{JH}$. Imaging of hypersensitivity pneumonitis. Radiologic Clinics. 2016;54(6): 1033-1046.

4. Quirce S, Vandenplas O, Campo P, Cruz MJ, De Blay F, Koschel $D$, et al. Occupational hypersensitivity pneumonitis: An EAACl position paper. Allergy. 2016;71(6): 765-779.

5. Sforza GG, Marinou A. Hypersensitivity pneumonitis: A complex lung disease. Clinical and Molecular Allergy. 2017;15(1): 1-8.

6. Sahin H, Kaproth-Joslin K, Hobbs SK. Hypersensitivity pneumonitis. Seminars in Roentgenology. 2019;54(1): 37-43.

7. Watts MM, Grammer LC. Hypersensitivity pneumonitis. Allergy \& Asthma Proceedings. 2019;40(6): 425-428.

8. Morell F, Villar A, Ojanguren I, Muñoz X, Cruz MJ. Hypersensitivity pneumonitis: Challenges in diagnosis and management, avoiding surgical lung biopsy. Seminars in Respiratory and Critical Care Medicine. 2016;37(3): 395-405.

9. Hogea SP, Tudorache E, Pescaru C, Marc M, Oancea C. Bronchoalveolar lavage: Role in the evaluation of pulmonary interstitial disease. Expert Review of Respiratory Medicine. 2020;14(11): 1117-1130.

10. Soumagne T, Dalphin JC. Current and emerging techniques for the diagnosis of hypersensitivity pneumonitis. Expert Review of Respiratory Medicine. 2018;12(6): 493-507. 